\title{
Real-time monitoring of superoxide anion radical generation in response to wounding: electrochemical study
}

\author{
Ankush Prasad ${ }^{\text {Corresp.. }}{ }^{1,2}$, Aditya Kumar ${ }^{1}$, Ryo Matsuoka ${ }^{3}$, Akemi Takahashi ${ }^{4}$, Ryo Fujii ${ }^{4}$, Yamato Sugiura ${ }^{4}$, \\ Hiroyuki Kikuchi ${ }^{4}$, Shigeo Aoyagi ${ }^{3}$, Tatsuo Aikawa ${ }^{5}$, Takeshi Kondo ${ }^{5}$, Makoto Yuasa ${ }^{5}$, Pavel Pospíšil ${ }^{1}$, \\ Shigenobu Kasai ${ }^{2,4}$ \\ ${ }^{1}$ Department of Biophysics, Centre of the Region Haná for Biotechnological and Agricultural Research, Faculty of Science, Palacký University, Olomouc, \\ Czech Republic \\ 2 Biomedical Engineering Research Center, Tohoku Institute of Technology, Sendai, Japan \\ 3 Hokuto Denko Corporation, Tokyo, Japan \\ 4 Graduate Department of Environmental Information Engineering, Tohoku Institute of Technology, Sendai, Japan \\ 5 Department of Pure and Applied Chemistry, Tokyo University of Science, Noda, Chiba, Japan \\ Corresponding Author: Ankush Prasad \\ Email address: prasad.ankush@gmail.com
}

Background: The growth and development of plants are deleteriously affected by various biotic and abiotic stress factors. Wounding in plants is caused by exposure to environmental stress, mechanical stress, and via herbivory. Typically, oxidative burst in response to wounding is associated with the formation of reactive oxygen species, such as the superoxide anion radical $\left(\mathrm{O}_{2}{ }^{-}\right)$, hydrogen peroxide $\left(\mathrm{H}_{2} \mathrm{O}_{2}\right)$ and singlet oxygen; however, few experimental studies have provided direct evidence of their detection in plants. Detection of $\mathrm{O}_{2}{ }^{-}$formation in plant tissues have been performed using various techniques including electron paramagnetic resonance spin-trap spectroscopy, epinephrineadrenochrome acceptor methods, staining with dyes such as tetrazolium dye and nitro blue tetrazolium (NBT), however, kinetic measurements have not been performed. In the current study, we provide evidence of $\mathrm{O}_{2} \cdot{ }^{--}$generation and its kinetics in the leaves of spinach (Spinacia oleracea) subjected to wounding.

Methods: Real-time monitoring of $\mathrm{O}_{2}{ }^{--}$generation was performed using catalytic amperometry. Changes in oxidation current for $\mathrm{O}_{2}{ }^{-}$was monitored using polymeric iron-porphyrin-based modified carbon electrodes $(\varphi=1 \mathrm{~mm})$ as working electrode with $\mathrm{Ag} / \mathrm{AgCl}$ as the reference electrode.

Result: The results obtained show a continuous generation of generation of $\mathrm{O}_{2}{ }^{--}$for minutes after wounding, followed by a decline. The exogenous addition of superoxide dismutase, which is known to dismutate $\mathrm{O}_{2}{ }^{\cdot-}$ to $\mathrm{H}_{2} \mathrm{O}_{2}$, significantly suppressed the oxidation current.

Conclusion: Catalytic amperometric measurements were performed using polymeric iron-porphyrin based modified carbon electrode. It is claimed to be a useful tool and a direct method for real-time monitoring and precise detection of $\mathrm{O}_{2}{ }^{--}$in biological samples. It is claimed to bear a potential for its wide application in plant research for specific and sensitive detection of $\mathrm{O}_{2}{ }^{\cdot-}$. 
1 Real-time monitoring of superoxide anion radical generation in

7 response to wounding: electrochemical study

Ankush Prasad ${ }^{1,2^{*}}$, Aditya Kumar ${ }^{1}$, Ryo Matsuoka ${ }^{3}$, Akemi Takahashi ${ }^{4}$, Ryo Fujii ${ }^{4}$, Yamato Sugiura $^{4}$, Hiroyuki Kikuchi ${ }^{4}$, Shigeo Aoyagi ${ }^{3}$, Tatsuo Aikawa ${ }^{5}$, Takeshi Kondo ${ }^{5}$, Makoto Yuasa ${ }^{5}$, Pavel Pospíšil ${ }^{1}$, Shigenobu Kasai ${ }^{\# 2,4}$

${ }^{1}$ Department of Biophysics, Centre of the Region Haná for Biotechnological and Agricultural Research, Faculty of Science, Palacký University, Olomouc, Czech Republic ${ }^{2}$ Biomedical Engineering Research Center, Tohoku Institute of Technology, Sendai, Japan. ${ }^{3}$ Hokuto Denko Corporation, Tokyo, Japan ${ }^{4}$ Graduate Department of Environmental Information Engineering, Tohoku Institute of Technology, Sendai, Japan.

${ }^{5}$ Department of Pure and Applied Chemistry, Tokyo University of Science, Noda, Chiba, Japan

*Corresponding author: Ankush Prasad, Department of Biophysics, Centre of the Region Haná for Biotechnological and Agricultural Research, Faculty of Science, Palacký University, Šlechtitelů 27, 78371 Olomouc, Czech Republic.

Tel. +420-58563-4752; fax: +420 585225737; E-mail address: ankush.prasad@upol.cz

\#Co-corresponding author: kasai@tohtech.ac.jp 


\section{Conclusion:}

\section{Background:}

\section{Methods:}

\section{Result:}

The growth and development of plants are deleteriously affected by various biotic and abiotic stress factors. Wounding in plants is caused by exposure to environmental stress, mechanical stress, and via herbivory. Typically, oxidative burst in response to wounding is associated with the formation of reactive oxygen species, such as the superoxide anion radical $\left(\mathrm{O}_{2}{ }^{--}\right)$, hydrogen peroxide $\left(\mathrm{H}_{2} \mathrm{O}_{2}\right)$ and singlet oxygen; however, few experimental studies have provided direct evidence of their detection in plants. Detection of $\mathrm{O}_{2}{ }^{--}$formation in plant tissues have been performed using various techniques including electron paramagnetic resonance spin-trap spectroscopy, epinephrine-adrenochrome acceptor methods, staining with dyes such as tetrazolium dye and nitro blue tetrazolium (NBT), however, kinetic measurements have not been performed. In the current study, we provide evidence of $\mathrm{O}_{2}{ }^{-}$- generation and its kinetics in the leaves of spinach (Spinacia oleracea) subjected to wounding.

Real-time monitoring of $\mathrm{O}_{2}{ }^{--}$generation was performed using catalytic amperometry. Changes in oxidation current for $\mathrm{O}_{2}{ }^{--}$was monitored using polymeric iron-porphyrin-based modified carbon electrodes $(\varphi=1 \mathrm{~mm})$ as working electrode with $\mathrm{Ag} / \mathrm{AgCl}$ as the reference electrode.

The results obtained show a continuous generation of $\mathrm{O}_{2}{ }^{--}$for minutes after wounding, followed by a decline. The exogenous addition of superoxide dismutase, which is known to dismutate $\mathrm{O}_{2}{ }^{--}$ to $\mathrm{H}_{2} \mathrm{O}_{2}$, significantly suppressed the oxidation current. 
48 Catalytic amperometric measurements were performed using polymeric iron-porphyrin based

49 modified carbon electrode. It is claimed to be a useful tool and a direct method for real-time

50 monitoring and precise detection of $\mathrm{O}_{2}{ }^{-}$in biological samples. It is claimed to bear a potential

51 for its wide application in plant research for specific and sensitive detection of $\mathrm{O}_{2}{ }^{\cdot-}$.

52

53

54

55

56

57

58

59

60

61

62

63

64

65

66

67

68

69

70 INTRODUCTION 

of photosynthesis [1-4]. The introduction of molecular oxygen into the environment by photosynthetic organisms during the evolution of aerobic life is associated with the formation of ROS [5]. Plants growing in a fluctuating environment are exposed to various biotic stresses such as bacteria, viruses, fungi, parasites, insects, weeds, etc. and abiotic stresses such as fluctuations in temperature, salinity, water, radiation, toxic chemicals and mechanical stress which are closely linked to higher ROS production. The chloroplasts, mitochondria, and peroxisomes are among the chief organelles involved [6-11]. As a response, ROS, including the superoxide anion radical $\left(\mathrm{O}_{2}{ }^{--}\right)$, hydroperoxyl radical $\left(\mathrm{HO}_{2}{ }^{--}\right)$, hydrogen peroxide $\left(\mathrm{H}_{2} \mathrm{O}_{2}\right)$, hydroxyl radical $(\mathrm{HO})^{\bullet}$, singlet oxygen $\left({ }^{1} \mathrm{O}_{2}\right)$, peroxyl radical (ROO*), hydroperoxide $(\mathrm{ROOH})$ and alkoxyl radical $\left(\mathrm{RO}^{*}\right)$, are produced [12-18].

The production of ROS by an oxidative burst is an imperative element of the wound response in algae, plants, and animals [19]. As a response to wounding, plants release oligosaccharide cell wall fragments, which play an important role in the signaling cascade that initiates an intense, localized production of ROS [20-22]. Wounding stimulates the production of $\mathrm{O}_{2}{ }^{--}, \mathrm{H}_{2} \mathrm{O}_{2}$ and nitric oxide (NO), which can directly attack encroaching pathogens at the site of the wound [23-25]. In Arabidopsis thaliana leaves measured under ambient light conditions, $\mathrm{O}_{2}{ }^{\cdot-}$ and $\mathrm{H}_{2} \mathrm{O}_{2}$ mainly originate from photosynthetic electron transport, predominantly at the site of wounding [26]. The role of NADPH oxidase in ROS production, however, was not completely ruled out. Therefore, the generation of $\mathrm{O}_{2}{ }^{--}$and $\mathrm{H}_{2} \mathrm{O}_{2}$ can be attributed to the collective effect of wounding and light stress. $\mathrm{O}_{2}^{--}$generation in the root cells of plants in response to wounding has

92 been studied by electron paramagnetic resonance (EPR) spin-trap spectroscopy and epinephrine-

93 adrenochrome acceptor methods [27]. Tiron (4, 5-dihydroxy-1, 3-benzene-disulfonic acid 
94 disodium salt) was used, and the tiron semiquinone EPR spectra showed $\mathrm{O}_{2}{ }^{\cdot-}$ generation. The 95 level of $\mathrm{O}_{2}^{--}$production in the roots was measured with epinephrine which, in the presence of $96 \mathrm{O}_{2}{ }^{--}$, is converted to adrenochrome and can be monitored at $480 \mathrm{~nm}$ by a spectrophotometer [28, 97 29]. In addition to spectroscopy, staining with dye, such as tetrazolium dye and nitro blue tetrazolium (NBT), has been used to detect the production of $\mathrm{O}_{2}{ }^{-}$in situ, with visualization of $\mathrm{O}_{2}^{\cdot-}$ generation as a purple formazan deposit within leaflet tissues [30].

Although various methods, such as EPR spin-trapping spectroscopy [31], chemiluminescence [32], the reduction of NBT [37, 38] and the reduction of the redox protein cytochrome $\mathrm{c}$ have been used to detect and monitor $\mathrm{O}_{2}{ }^{--}$, each of these methods has inadequate specificity and sensitivity. EPR spin-trapping spectroscopy is one of the most sensitive and specific method for ROS detection; however, kinetic measurements are not possible at the current stage of development. Chemiluminescence, also known as ultra-weak photon emission, has been widely used recently as a non-invasive method to understand the involvement of ROS in oxidative radical reactions [36-38]; however, limitations with respect to the specificity for particular ROS involvement exists [39].

Integration of metalloporphyrins into electropolymerized polymer electrodes have been developed rigorously over the last years because these materials are effective electrocatalysts for chemical as well as photochemical applications [40]. Numerous authors have recently tested the potential use of electropolymerized metalloporphyrins as new electrode materials for chemical and biological sensors [41-43]. In our current study, we provide an experimental approach for the detection of $\mathrm{O}_{2}{ }^{\cdot-}$ by polymeric iron-porphyrin-based modified carbon electrode based on the reaction mechanism presented in Fig. 1A (Yuasa \& Oyaizu, 2005). Detection of $\mathrm{O}_{2}{ }^{--}$by highly sensitive and selective polymeric iron-porphyrin-based modified carbon electrodes was tested in 
117 in vivo leaf sample subjected to wounding. The current study introduces the use of catalytic

118 amperometric biosensors for the real-time detection of $\mathrm{O}_{2}{ }^{\cdot-}$.

119

120 MATERIAL AND METHODS

121

122 Spinach leaves

$123 \quad$ Young spinach (Spinacia oleracea) leaves were washed twice with deionized water and 124 were dark adapted for 2 hours. For each measurement, a fresh spinach leaf of the approximately 125 same age was chosen. All experiments were performed at room temperature under dark 126 conditions to avoid interference from light sources.

127

128

Material and chemical reagents

The 5-(ethoxycarbonyl)-5-methyl-1-pyrroline N-oxide (EMPO) spin trap and capillary 130 tubes used for EPR measurements were obtained from Alexis Biochemicals (Lausen,

131 Switzerland) and Blaubrand intraMARK (Brand, Germany), respectively. The carbon electrodes $132(\varphi=1 \mathrm{~mm})$ were purchased from BAS Inc., ALS Co., Ltd. (Tokyo, Japan). Superoxide dismutase 133 (SOD), xanthine oxidase and xanthine $(\mathrm{X} / \mathrm{XO})$ were purchased from Wako Pure Chemicals 134 Industries, Ltd. (Osaka, Japan), Sigma-Aldrich chemie Gmbh (Munich, Germany) or Sigma135 Aldrich Japan K.K. (Tokyo, Japan).

136 137 138 Equipment and methods 

potentiostat (HA1010mM4S; Hokuto Denko Co., Ltd., Japan). The polymeric iron-porphyrinbased modified carbon electrodes were positioned $1 \mathrm{~mm}$ from the site of injury using a motor-

142 driven XYZ-stage (K101-20MS-M, Suruga Seiki Co., Ltd., Japan) (Fig. 1B). The detection of $\mathrm{O}_{2}{ }^{--}$in the $\mathrm{X} / \mathrm{XO}$ system was performed by EPR spin-trapping spectroscopy using $25 \mathrm{mM}$ EMPO in phosphate buffer.

\section{Experimental conditions for real-time monitoring of the oxidation current of $\mathrm{O}_{2}{ }^{--}$}

The electrochemical detection of $\mathrm{O}_{2}{ }^{--}$was measured using the $\mathrm{X} / \mathrm{XO}$ system based on the method described in our recent study [44] (Fig. 2). The subsequent oxidation current for $\mathrm{O}_{2}{ }^{--}$was monitored using polymeric iron-porphyrin-based modified carbon electrodes $(\varphi=1 \mathrm{~mm})$ with $\mathrm{Ag} / \mathrm{AgCl}$ as the reference electrode. adhesive tape. $10 \mathrm{mM}$ Phosphate buffer saline (pH 7.2) (PBS) was gradually added to maintain a sufficient volume to submerge the whole spinach leaf in PBS. During the measurement, injury was performed using glass capillary with an inner diameter of about $1.2 \mathrm{~mm}$ and wall thickness of $200 \mu \mathrm{m}$ as presented in Fig. 1B and DataS1. For data presented in the manuscript, the injury/wounding in spinach leaves were done either 1 time or multiple times (between 8-10 times) while to visualize the state of leaves, injury/wounding was made 1 time, 5 times and 20 times (DataS1). Mechanical injury and mechanical wounding were performed close to the site of 
161

162

163

164

165

166

167

168

169

170

171

172

173

174

175

176

177

178

179

180

181

182

183

\section{Superoxide anion radical detection using polymeric iron-porphyrin-based modified carbon} electrodes

The detection of $\mathrm{O}_{2}^{\cdot-}$ was based on catalytic amperometry using a counter electrode and working electrode. The counter electrode was a platinum wire $(\phi 0.25 \times 40 \mathrm{~mm})$, and the working electrode $(\varphi 1 \mathrm{~mm})$ was a polymeric iron-porphyrin-based modified carbon electrode. $\mathrm{Ag} / \mathrm{AgCl}$ was used as a reference electrode. The polymeric iron-porphyrin-based modified carbon electrode acted as an $\mathrm{O}_{2}{ }^{--}$detection sensor. The polymeric iron-porphyrin-based modified carbon electrode was prepared by the electropolymerization of 1-methylimidazole-coordinated mesotetra (3-thienyl) porphyrin $\left(\left[\mathrm{Fe}(\mathrm{im})_{2}(\mathrm{ttp})\right] \mathrm{Br}\right)$ (Yuasa \& Oyaizu, 2005; Yuasa et al., 2005).

Electropolymerization was performed in a two-chamber three-electrode electrochemical cell by potential cycling from 0 to $+2.0 \mathrm{~V}$ vs. $\mathrm{Ag} / \mathrm{Ag}^{+}$with a potential sweep rate of $50 \mathrm{mV} \mathrm{s}$. After rinsing with dichloromethane, the polymeric iron-porphyrin-based modified carbon electrode was obtained (Yuasa \& Oyaizu, 2005; Yuasa et al., 2005). For the basic characterization of the polymeric iron-porphyrin-based modified carbon electrode, a differential pulse voltammogram of the electropolymerized $\left[\mathrm{Fe}(\mathrm{im})_{2}(\mathrm{ttp})\right] \mathrm{Br}$ complex was recorded in an aqueous electrolyte solution containing 10 mM PBS (pH 7.2) using a high-performance potentiostat HZ-7000 (Hokuto Denko Co., Ltd., Japan) (supplementary data S2).

\section{RESULTS}

Characterization and sensitivity evaluation of an iron-porphyrin-based modified carbon electrode

The characterization of the polymeric iron-porphyrin-based modified carbon electrode was performed using a differential pulse voltammogram (DPV) (supplementary data S2). The 
184 polymerized complex was electroactive, with a mean redox potential at $-0.25 \mathrm{~V}$ for the $\mathrm{Fe}^{2+} / \mathrm{Fe}^{3+}$ 185 couple.

186

187

188

190

191

192

193

194

195

196

197

198

199

200

201

202

203

204

205

206

Generation of $\mathrm{O}_{2}^{\cdot-}$ in the chemical system and sensitivity evaluation of the polymeric ironporphyrin-based modified carbon electrode

The xanthine/xanthine oxidase system is used for the formation of $\mathrm{O}_{2}^{--}$by the reduction of molecular oxygen [45-47]. To confirm the formation of $\mathrm{O}_{2}^{--}$in the chemical system used in the later experimental procedures, we measured the EMPO-OOH adduct EPR signal (supplementary data S3: A). The intensity of the EMPO-OOH adduct EPR signal in the control (xanthine) and chemical system $(\mathrm{X} / \mathrm{XO})$ was also measured (supplementary data $\mathrm{S} 3$ : $\mathrm{B}$ ). In the absence of xanthine oxidase, no EMPO-OOH adduct EPR signal was observed, whereas in the presence of XO, an EMPO-OOH adduct EPR signal was observed (supplementary data S3).

To determine the sensitivity of the polymeric iron-porphyrin-based modified carbon electrode, the response of the exogenous addition of a standard known concentration of $\mathrm{O}_{2}{ }^{--}$ generated in situ was measured using X/XO system. A linear increase in oxidation current was observed with an increase in $\mathrm{O}_{2}{ }^{--}$concentration. The calibration curve $\left(\Delta i\right.$ vs $\left.\mathrm{O}_{2}{ }^{--}\right)$was found to be linear in the concentration range of 0.4 to $1.3 \mu \mathrm{M}$ (Fig. 2). This indicates that the sensitivity of the electrochemical sensor is in the range of $\mu \mathrm{M}$ concentration, reflecting changes in the oxidation current in the order of tens of nA (Fig. 2).

\section{Real-time monitoring of $\mathrm{O}_{2}^{\cdot-}$ generation during wounding of spinach leaves}

To validate that there is no interference in the measurement caused by the suspension of spinach leaf in PBS, the oxidation current was measured in a non-wounded spinach leaf 
207 suspended in PBS (Fig. 3). No fluctuation in the oxidation current of $\mathrm{O}_{2}{ }^{--}$was observed in the 208 non-wounded spinach leaf suspended in PBS, (Fig. 3), whereas a negligible fluctuation was 209 observed with the exogenous addition of SOD (data not shown). These results indicate that these 210 chemical species (PBS and SOD) do not interfere with the measurements. The kinetics of the 211 production of $\mathrm{O}_{2}{ }^{--}$were also measured in the chemical system containing no spinach leaves and 212 in the presence of SOD $\left(400 \mathrm{U} \mathrm{ml}^{-1}\right)$ indicating no significant fluctuation in oxidation current 213 (supplementary data S4).

214 Real-time monitoring of the oxidation current for $\mathrm{O}_{2}{ }^{--}$was performed in spinach leaves 215 where mechanical injury was stimulated 1 time using glass tube (Fig. 4A) and mechanical wounding was done multiple times (Fig. 4B). The wounding in spinach leaves was done 1 time

217 (4A) and multiple times (between 8-10 times) using a glass capillary with an inner diameter of about $1.2 \mathrm{~mm}$ and wall thickness of $200 \mu \mathrm{m})$. The results indicate that the $\mathrm{O}_{2}^{\cdot-}$ production increased considerably with the dose of mechanical injury (Fig. 4). Furthermore, to visualize the extent of damage to leaf during mechanical injury induced by glass capillary, photograph of leaves showing the physiological state have been presented along with kinetics on real-time monitoring of the oxidation current of $\mathrm{O}_{2}{ }^{\cdot-}$ under experimental condition mentioned in dataset presented (Data S1). To determine the concentration of $\mathrm{O}_{2}{ }^{--}$generated in mechanically injured spinach leaves, the calibration curve was established for various concentrations obtained using standard X/XO system (Fig. 2). A maximum oxidation current ( $\Delta \mathrm{i}$ ) of $1.5 \mathrm{nA}$ (at time span, 60 sec) and $7.5 \mathrm{nA}$ (at time span, $300 \mathrm{sec}$ ) was observed in mechanically injury made at a minimal

227 dose (Fig. 4A) and at multiple sites (Fig. 4B). Based on the data obtained and the maximum oxidation current recorded, the $\mathrm{O}_{2}{ }^{--}$was calculated and expected production was found to be

229 about $40 \mathrm{nM}(4 \mathrm{~A})$ and $200 \mathrm{nM}(4 \mathrm{~B})$ (Table 1). 
In addition, $\mathrm{O}_{2}^{--}$generation was also measured in spinach leaves under the effect of

231

232

233

234

235

236

237

238

239

240

241

242

wounding at room temperature in presence of exogenous addition of SOD (Fig. 5). In the absence of wounding, as observed during the first minute of real-time monitoring, no considerable change in the oxidation currents of $\mathrm{O}_{2}{ }^{--}$was observed. However, wounding instantaneously resulted in a fast increase in the oxidation current for $\mathrm{O}_{2}{ }^{--}$of approximately 10 $\mathrm{nA}$, followed by a gradual decrease, which continued for more than $10 \mathrm{~min}$. To confirm the production of $\mathrm{O}_{2}{ }^{--}$, the effect of SOD, which leads to the dismutation of $\mathrm{O}_{2}{ }^{--}$to $\mathrm{H}_{2} \mathrm{O}_{2}$, on the oxidation current in a wounded spinach leaf was analyzed. The addition of $400 \mathrm{U} \mathrm{ml}^{-1} \mathrm{SOD}$ suppressed the oxidation current for $\mathrm{O}_{2}{ }^{--}$from $3.5 \mathrm{nA}$ to $2 \mathrm{nA}$ (Fig. 5). However, complete suppression of the oxidation current was not observed. The oxidation current, which persisted at approximately $1 \mathrm{nA}$ for a few minutes, can be attributed to rapid $\mathrm{O}_{2}{ }^{--}$diffusion to the electrode before its conversion to $\mathrm{H}_{2} \mathrm{O}_{2}$ or to the limited SOD activity at a fixed concentration. The effect of SOD (400 $\mathrm{U} \mathrm{ml}^{-1}$ ) added exogenously was also measured at the point of maximum oxidation current where a comparatively higher suppression was recorded (Fig. 6).

\section{DISCUSSION}

In addition to plants, ROS detections have been performed in model system including animals. During recent past, Zuo and coworkers presented results on intracellular ROS formation in single isolated frog myofibers during low $\mathrm{P}_{\mathrm{O} 2}$ conditions using dihydrofluorescein (Hfluor), a fluorescein analog of DCFH $[48,49]$. Cyt c assay was also used to measure $\mathrm{O}_{2}{ }^{--}$in contracting skeletal muscle in pulmonary TNF- $\alpha$ overexpression mice $[50,51]$. Several mechanisms for the generation of ROS involving $\mathrm{O}_{2}{ }^{--}$have been suggested. It has been proposed previously that an NADPH oxidase-like enzyme in the plant plasma membrane is involved in the production of $\mathrm{O}_{2}{ }^{--}$, 
253 which is then converted to the more stable $\mathrm{H}_{2} \mathrm{O}_{2}$ during the oxidative burst in response to 254 pathogen attack of plant cells $[52,53]$. In skeletal muscle, the major source of ROS especially 255 extracellular $\mathrm{O}_{2}{ }^{--}$formation is via the arachidonic acid metabolism through lipoxygenase (LOX) 256 activity [51]. However, in contrast to the view that wound-induced ROS are primarily produced 257 extracellularly by NADPH oxidase enzymes [54, 55], it has been recently indicated that wound258 induced $\mathrm{O}_{2}^{\cdot-}$ and $\mathrm{H}_{2} \mathrm{O}_{2}$ originate from photosynthetic electron transport measured at wounded 259 sites under ambient light conditions [26]. The $\mathrm{O}_{2}{ }^{--}$is produced during the electron transport 260 process by the reduction of molecular oxygen in the chloroplasts and mitochondria. The authors 261 proposed that $\mathrm{O}_{2}{ }^{--}$and $\mathrm{H}_{2} \mathrm{O}_{2}$ production is linked to wounding, which is enhanced significantly 262 under light conditions.

263 A recent report on Pisum sativum seedlings proposes a mechanism responsible for 264 oxidative burst during wounding. During mechanical wounding, polyunsaturated fatty acids 265 (PUFA), polyamines, LOX and peroxidases (Prx) are released in the extracellular matrix. Under 266 these circumstances, LOX is involved in the oxidation of PUFA or polyamines, which induces 267 diamine oxidases (DAO) to produce $\mathrm{H}_{2} \mathrm{O}_{2}$, further leading to $\mathrm{O}_{2}{ }^{\cdot-}$ production catalyzed by Prx 268 [56]. A diverse range of organisms use Prx to produce $\mathrm{O}_{2}{ }^{\cdot-}$, e.g., Triticum sativum roots [57], 269 Castanea sativa and Trichilia seeds [58, 59], liverworts [60], and lichens [61]. Another group of 270 redox enzyme involved in the wound-induced oxidative burst is DAO [62-65], and cooperation 271 between DAO and Prx is considered important in the wound response. In addition to DAO and 272 Prx, LOX not only generates lipid hydroperoxides (LOOH) but can also generate $\mathrm{O}_{2}{ }^{--}$via the 273 oxidation of pyridine nucleotides and therefore considerably contributes to oxidative stress in 274 cells [66]. Lipid oxidation by LOX is an important part of the wound-response because oxylipins, 275 the break-down products of lipid peroxides, can act as effective signaling molecules to rapidly 
276 induce transcriptional changes during wounding [67, 68]. Plasma membrane-bound Prx can

277 utilize PUFA such as linoleic acid released at the wound site for the synthesis of $\mathrm{O}_{2}{ }^{\cdot-}$. Even if

278 LOX is not known to be directly involved in $\mathrm{O}_{2}{ }^{-}$- production, it was suggested that extracellular

279 LOX may play an important role by competing with Prx for fatty acids and producing reactive

280 electrophiles that coordinate signaling responses [53].

281 The electrochemical method with the employment of different modified electrodes have

282 been successfully standardized and applied for detection of varied ROS including $\mathrm{O}_{2}^{\cdot-}$ during

283 the recent past [69-71]. The polymeric iron-porphyrin-based modified carbon electrode is a

284 useful tool and provides a direct method for real-time monitoring and precise detection of $\mathrm{O}_{2}{ }^{--}$in

285 biological samples in-situ [71]. The kinetic measurement showing the production of $\mathrm{O}_{2}^{\cdot-}$ for a

286 long range of time (minutes) presented in our study

287 (https://ecs.confex.com/ecs/229/webprogram/Paper70675.html) have been demonstrated and thus

288 opens a new area of investigation which have always been difficult to explore using other

289 available methods such as EPR spin trapping spectroscopy, fluorescence microscopy and other

290 biochemical methods etc. Thus, the electrode has strong potential for wide application in plant

291 research for the specific and sensitive detection of $\mathrm{O}_{2}^{--}$and the kinetic behavior in real-time. In

292 addition to points mentioned above, using synthetic porphyrin has an additional advantage. To

293 date, $\mathrm{O}_{2}{ }^{--}$sensors based on naturally derived enzyme (e.g. SOD, Cyt. c) have been developed

294 [72]. However, enzymes on the sensor are likely to be denatured. In contrast, the porphyrin based

295 sensor can be used without denaturation. At the same time, the current method is cost effective.

296 Certain limitations exist; the current polymeric iron-porphyrin-based modified carbon electrodes

297 are light-sensitive, which might hinder its photo-electrochemical applicability [73]. In the current

298 study, we present our polymeric iron-porphyrin based modified carbon electrode for application 
299 in real-time monitoring and precise detection of $\mathrm{O}_{2}{ }^{--}$in biological system. It is claimed to bear a 300 potential for its wide application in plant research for specific and sensitive detection of $\mathrm{O}_{2}{ }^{\cdot-}$.

301

302

303

304

305

306

307

308

309

310

311

312

313

314

315

\section{FIGURE LEGENDS}

Figure 1: Reaction mechanism and experimental setup. (A) Schematic illustration of the reaction mechanism for the amperometric detection of $\mathrm{O}_{2}{ }^{--}$using the polymeric iron-porphyrinbased modified carbon electrode depicting the reduction-oxidation cycle leading to generation of the oxidation current. (B) Schematic illustration of the experimental setup for the electrochemical measurements. The stimulation was performed using a glass capillary, and the polymeric iron-porphyrin-based modified carbon electron was positioned at a distance of $1 \mathrm{~mm}$ using a motor-driven XYZmicroscopic stage (I). The in vivo generation of $\mathrm{O}_{2}{ }^{--}$was measured using a polymeric iron-porphyrin-based modified carbon electron (working electrode, WE), platinum wire (counter electrode, $\mathrm{CE}$ ) and $\mathrm{Ag} / \mathrm{AgCl}$ (reference electrode, $\mathrm{RE}$ ) (II).

Figure 2: Calibration curve. Changes in oxidation current measured using iron-porphyrinbased modified carbon electrode by exogenous addition of a standard known concentration of $\mathrm{O}_{2}{ }^{\cdot-}$ generated in situ using $\mathrm{X} / \mathrm{XO}$ system in the concentration range of 0.4 to $1.3 \mu \mathrm{M}$.

\section{Figure 3: Real-time monitoring of the oxidation current of $\mathrm{O}_{2}{ }^{-}$from spinach leaves. The} kinetics of the production of $\mathrm{O}_{2}{ }^{\cdot-}$ was measured using a polymeric iron-porphyrin-based modified carbon electrode on non-wounded spinach leaves.

Figure 4: Real-time monitoring of oxidation current for $\mathrm{O}_{2}{ }^{--}$during wounding. The kinetics of the production of $\mathrm{O}_{2}{ }^{--}$were measured using a polymeric iron porphyrin based modified carbon 
321 electrode during wounding in spinach leaves. The wounding in spinach leaves was done 1 time

322 (A) and multiple times (B) close to the site of electrode during the measurement and oxidation

323 current for $\mathrm{O}_{2}{ }^{--}$was measured.

324 Figure 5: Real-time monitoring of the oxidation current of $\mathrm{O}_{2}{ }^{--}$during wounding. The

325 kinetics of the production of $\mathrm{O}_{2}{ }^{--}$were measured using a polymeric iron-porphyrin-based

326 modified carbon electrode during wounding in spinach leaves. The wounding of spinach leaves

327 was performed during the measurement, and the oxidation current for $\mathrm{O}_{2}{ }^{\cdot-}$ was measured for

328 approximately $30 \mathrm{~min}$. The effect of SOD on the oxidation current was measured in the presence

329 of SOD (400 $\left.\mathrm{U} \mathrm{ml}^{-1}\right)$ added exogenously during the measurement.

330

331

332

333

334

335

336

337

338

339

340

341

Figure 6: Real-time monitoring of oxidation current for $\mathrm{O}_{2}{ }^{--}$during wounding. The kinetics of the production of $\mathrm{O}_{2}^{--}$was measured using a polymeric iron porphyrin based modified carbon electrode during wounding in spinach leaves. The wounding in spinach leaves was done during the measurement and oxidation current for $\mathrm{O}_{2}{ }^{-}$was measured for a duration of about $30 \mathrm{~min}$. Effect of SOD was measured in the presence of SOD (400 $\left.\mathrm{Ul}^{-1}\right)$ added exogenously during the measurement at the point of maximum oxidation current.

Table 1: Calculation. Superoxide anion radical $\left(\mathrm{O}_{2}{ }^{--}\right)$concentration calculated using standard calibration curve $\left(\mathrm{R}^{2}=0.9918\right)$ (Fig. 2$)$. The total change in oxidation current was found to be 1.5 $\mathrm{nA}(\Delta \mathrm{i})$ for minimal dose of injury (Fig. 4A) and $7.5 \mathrm{nA}(\Delta \mathrm{i})$ for injury at multiple sites (Fig. 4B). The total $\mathrm{O}_{2}{ }^{--}$concentration was found to be equivalent to $40 \mathrm{nM}$ (Fig. 4A) and $200 \mathrm{nM}$ (Fig. 4B) at $60 \mathrm{sec}$ and $300 \mathrm{sec}$, respectively. 


\section{SUPPLEMENTARY DATA}

343 Supplementary data S1: Photographs of glass capillary (4 nos.) each with an inner diameter of 344 about $1.2 \mathrm{~mm}$ and wall thickness of $200 \mu \mathrm{m}$ used for inducing mechanical injury in spinach leaves.

345 II. (A) Photograph of Spinach leaves in the experimental setup. For each measurement, young 346 spinach leaves of size approximately $8-10 \mathrm{~mm}$ were chosen. (B) Photographs of petriplate with 347 Spinach leaves showing the arrangement of electrodes. III. Photographs of Spinach leaves 348 showing its state after mechanical injury with glass capillary. Injury was made 1 time (A), 5 349 times (B) and 20 times (C). IV. The kinetics of the production of $\mathrm{O}_{2}{ }^{--}$was measured using a 350 polymeric iron porphyrin based modified carbon electrode during wounding in spinach leaves 351 (arrow indicates mechanical wounding). The wounding in spinach leaves was done 20 times 352 close to the site of electrode during the measurement and oxidation current for $\mathrm{O}_{2}{ }^{--}$was 353 measured.

Supplementary data S2: DPV for the electropolymerized [Fe(im)2(ttp)]Br complex recorded in an aqueous electrolyte solution containing phosphate buffer ( $\mathrm{pH}$ 7.2).

Supplementary data S3: EMPO-OOH adduct EPR spectra were measured in the presence of 25 $\mathrm{mM}$ EMPO, $40 \mathrm{mM}$ phosphate buffer $(\mathrm{pH} 7.2)$ in the absence and presence of xanthine (1 $\mathrm{mM})$ and xanthine oxidase $\left(0.2 \mathrm{U} \mathrm{ml}^{-1}\right)$. Panel (A) shows the spectra measured in the phosphate buffer only (trace a) and $\mathrm{X} / \mathrm{XO}$ system (trace b); (B) mean value $\pm \mathrm{SD}, \mathrm{n}=3$, of the EMPO-OOH adduct EPR spectra. The intensity of the EPR signal depicted in (B) was evaluated by measuring the relative height of the central peak of the first derivative of the EPR absorption spectrum. 
365

366

367

368

369

370

371

372

373

374

375

376

377

378

379

380

381

382

383

384

385

386

Supplementary data S4: Kinetics of the production of $\mathrm{O}_{2}{ }^{--}$was measured using polymeric iron porphyrin based modified carbon electrode in the chemical system (phosphate buffer) in the presence of SOD (400U ml-1).

\section{REFERENCES}

1. Ledford HK, Chin BL, and Niyogi KK. Acclimation to singlet oxygen stress in Chlamydomonas reinhardtii. Eukaryotic Cell. 2007; 6: 919-930.

2. Alessandro A, Osto LD, Aprile A, Carillo P, Roncaglia E, Cattivelli L, Bassi R. Reactive oxygen species and transcript analysis upon excess light treatment in wildtype Arabidopsis thaliana vs a photosensitive mutant lacking zeaxanthin and lutein. BMC Plant Biology. 2011; 11: 62.

3. Foyer $\mathrm{CH}$, and Shigeoka S. Understanding Oxidative Stress and Antioxidant Functions to Enhance Photosynthesis. Plant Physiology. 2011; 155: 93-100.

4. Laloi C, and Havaux M. Key players of singlet oxygen-induced cell death in plants. Frontiers in Plant Science. 2015; 6: 39.

5. Tripathy BC, Oelmüller R. Reactive oxygen species generation and signaling in plants. Plant Signaling and Behavior. 2012; 7(12): 1621-1633.

6. Elstner EF. Mechanisms of oxygen activation in different compartments of plant cells, in Active Oxygen/Oxidative Stress and Plant Metabolism, E. J. Pell and K. L. Steffen, Eds., pp. 13-25, American Society of Plant Physiologists, Rockville, Md, USA. 1991.

7. Foyer $\mathrm{CH}$, and Harbinson J. "Oxygen metabolism and the regulation of photosynthetic electron transport," in Causes of Photooxidative Stresses and Amelioration of Defense 

Raton, Fla, USA. 1994.

8. Asada K. Radical production and scavenging in the chloroplasts," in Photosynthesis and the Environment, N. R. Baker, Ed., pp. 123-150, Kluwer, Dordrecht, The Netherlands. 
17. Bhattacharjee S. Sites of generation and physicochemical basis of formation of reactive

411

412

413

414

415

416

417

418

419

420

421

422

423

424

425

426

427

428

429

430

431

432 oxygen species in plant cell, in Reactive Oxygen Species and Antioxidants in Higher Plants. S. Dutta Gupta, Ed., pp. 1-30, CRC Press, New York, NY, USA. 2010.

18. Choudhury S, Panda P, Sahoo L, and Panda SK. Reactive oxygen species signalling in plants under abiotic stress. Plant Signaling \& Behaviour. 2013; 8: e23681.

19. McDowell RE, Amsler MO, Li Q, Lancaster Jr JR, Amsler CD. The immediate woundinduced oxidative burst of Saccharina latissimi depends on light via photosynthetic electron transport. Journal of Phycology. 2015; 51: 431-441.

20. Legendre L, Rueter S, Heinstein PF, Low PS. Characterization of the oligogalacturonideinduced oxidative cells. Plant Physiology. 1993; 102: 233-240.

21. John M, Rohrig G, Schmidt J, Walden R, Schell J. Cell signaling by oligosaccharides. Trends in Plant Science. 1997; 2: 111-115.

22. Stennis M, Chandra S, Ryan C, Low P. Systemin potentiates the oxidative burst in cultured tomato cells. Plant Physiology. 1998; 117: 1031-1036.

23. Murphy TM, Asard H, Cross AR. Possible sources of reactive oxygen during the oxidative burst in plants. In: Asard, H., Berczi, A. (Eds.), Plasma Membrane Redox Systems and their Role in Biological Stresses and Disease. Kluwer Academic Publishers, Dordrecht, pp. 215-246. 1998.

24. Garces H, Durzan D, Pedroso MC. Mechanical stress elicits nitric oxide formation and DNA fragmentation in Arabidopsis thaliana. Annals of Botany. 2001; 87: 567-574.

25. Jih PJ, Chen YC, Jeng ST. Involvement of hydrogen peroxide and nitric oxide in expression of the ipomoelin gene from sweet potato. Plant Physiology. 2003; 132: 381389. 
433

434

435

436

437

438

439

440

441

442

443

444

445

446

447

448

449

450

451

452

453
26. Morker KH, Roberts MR. Light as both an input and an output of wound-induced reactive oxygen formation in Arabidopsis leaves. Plant Signaling and Behaviour. 2011; 6(8): 1-3.

27. Vylegzhaninat NN, Gordon LK, Minibayeva FV, Kolesnikov OP. Superoxide Production as a Stress Response of Wounded Root Cells: ESR Spin-Trap and Acceptor Methods. Applied Magnetic Resonance. 2001; 21: 63-70.

28. Misra HR, Fridovich I. The Univalent Reduction of Oxygen by Reduced Flavins and Quinones. The Journal of Biological Chemistry. 1972; 247: 188-192.

29. Barber MJ, Kay CJ. Superoxide production during reduction of molecular oxygen by assimilatory nitrate reductase. Archives of Biochemistry and Biophysics. 1996; 326: 227232.

30. Wohlgemuth H, Mittelstrass K, Kschieschan S, Bender J, Weigel HJ, Overmyer K, Kangasjärvi J, Sandermann H, Langebartels C. Activation of an oxidative burst is a general feature of sensitive plants exposed to the air pollutant ozone. Plant Cell Environment. 2002; 25: 717-726.

31. Von GM, Schlosser E, Neubacher H. Evidence from electron-spin resonance for the formation of free radicals during infection of Avena sativa by Drechslera spp. Physiology and Molecular Plant Pathology. 1993; 42: 405-412.

32. Anderson AA, Rogers K, Tepper CS, Blee K, Cardon J. Timing of molecular events following elicitor treatment of plant cells. Physiology and Molecular Plant Pathology 1991; 38: 1-13. 
454

455

456

457

458

459

460

461

462

463

464

465

466

467

468

469

470

471

472

473

474
33. Doke N. Involvement of superoxide anion generation in the hypersensitive response of potato tuber tissues to infection with an incompatible race of Phytophthora infestans and to the hyphal wall components. Physiological Plant Pathology. 1983; 23: 345-357.

34. Doke N. Generation of superoxide anion by potato tuber protoplasts during the hypersensitive response to hyphal wall components of Phytophthora infestans and specific inhibition of the reaction by suppressors of hypersensitivity. Physiological Plant Pathology. 1983; 23: 359-367.

35. Doke N. NADPH-dependent $\mathrm{O}_{2}{ }^{-}$- generation in membrane fractions isolated from wounded potato tubers inoculated with Phytophthora infestans. Physiological Plant Pathology. 1985; 27: 311-322.

36. Prasad A and Pospíšil P. Ultraweak photon emission induced by visible light and ultraviolet A radiation via photoactivated skin chromophores: in vivo charge coupled device imaging. Journal of Biomedical Optics. 2012; 17(8): 85004.

37. Prasad A and Pospíšil P. Towards the two-dimensional imaging of spontaneous ultraweak photon emission from microbial, plant and animal cells. Scientific Reports. 2013; 3: 1211.

38. Pospíšil P, Prasad A and Rác M. Role of reactive oxygen species in ultra-weak photon emission in biological systems. Journal of Photochemistry and Photobiology B: Biology $.2014 ; 139: 11-23$

39. Halliwell B, Gutteridge JMC. Free Radicals in Biology and Medicine, Ed 2. Clarendon Press, Oxford, UK. 1989. 
475

476

477

478

479

480

481

482

483

484

485

486

487

488

489

490

491

492

493

494

495

496
40. Bedioui F, Devynck J and Charreton CB. Immobilization of metalloporphyrins in electropolymerized films: design and applications. Accounts of Chemical Research. $1995 ; 28(1), 30-36$

41. Deronzier A, and Moutet JC. Polypyrrole films containing metal complexes: syntheses and applications. Coordination Chemistry Reviews. 1996; 147, 339-371.

42. Yim HS, Kibbey CE, Ma SC, Kliza DM, Liu D, Park SB, Terre CE and Meyerhoff ME. Polymer membrane-based ion-, gas- and bio-selective potentiometric sensors. Biosensors and Bioelectronics. 1993; 8,1-38.

43. Bedioui F, Trevin S, and Devynck J. Chemically modified microelectrodes designed for the electrochemical determination of nitric oxide in biological systems. Electroanalysis. 1996; 8, 1085-1091.

44. Matsuoka R, Igarashi M, Kondo $\mathrm{T}$, Aikawa $\mathrm{T}$, and Yuasa M. Biomimetic antithrombogenic electrochemical superoxide anion radical sensor. Journal of the Electrochemical Society. 2014; 161:6.

45. Olson JS, Ballou DP, Palmer GS, Massey V. The Reaction of Xanthine Oxidase with Molecular Oxygen. The Journal of Biological Chemistry. 1974; 249: 4350-4362.

46. Richter C. Redox intermediates between $\mathrm{O}_{2}$ and $\mathrm{H}_{2} \mathrm{O}$. Membrane Biochemistry. A Laboratory Manual on Transport and Bioenergetics. doi: 10.1007/978-3-642-67530-0_12. 1979.

47. Porras AG, Olson JS, Palmer G. The reaction of reduced xanthine oxidase with oxygen. Kinetics of peroxide and superoxide formation. The Journal of Biological Chemistry. 1981; 256: 9096-9103. 
497

498

499

500

501

502

503

504

505

506

507

508

509

510

511

512

513

514

515

516

517

518

48. Zuo L, Nogueira L and Hogan MC. Reactive oxygen species formation during tetanic contractions in single isolated Xenopus myofibers. Journal of Applied Physiology. 2011; 111: 898-904.

49. Zuo L, Shiah A, Roberts WJ, Chien MT, Wagner PD and Hogan MC. Low $\mathrm{P}_{\mathrm{O} 2}$ Conditions Induce Reactive Oxygen Species Formation during Contractions in Single Skeletal Muscle Fibers. American Journal of Physiology. Regulatory, integrative and Comparative Physiology. 2013; 304 (11): R1009-16.

50. Zuo L, Hallman AH, Roberts WJ, Wagner PD, Hogan MC. Superoxide release from contracting skeletal muscle in pulmonary TNF- $\alpha$ overexpression mice. American Journal of Physiology. Regulatory, integrative and Comparative Physiology. 2014; 306(1): R75R81.

51. Zuo L, Christofi FL, Wright VP, Bao S, Clanton TL. Lipoxygenase-dependent superoxide release in skeletal muscle. Journal of Applied Physiology. 2004; 97(2):661668.

52. Murphy TM, Auh CK. The Superoxide Synthases of Plasma Membrane Preparations from Cultured Rose Cells. Plant Physiology. 1996; 110: 621-629.

53. Doke N, Miura J, Sanchez LM, Park HJ, Noritake T, Yoshioka H, Kawakita K. The oxidative burst protects plants against pathogen attack: mechanism and role as an emergency signal for plant bio-defence- a review. Gene. 1996; 179: 45-5.

54. Watanabe T, Sakai S. Effects of active oxygen species and methyl jasmonate on expression of the gene for a wound-inducible 1-aminocyclopropane-1-carboxylate synthase in winter squash (C. maxima). Planta. 1998; 206: 570-576. 
519

520

521

522

523

524

525

526

527

528

529

530

531

532

533

534

535

536

537

538

539

540
55. Flor-Henry M, McCabe TC, Bruxelles GL de, Roberts MR. Use of a highly sensitive two-dimensional luminescence imaging system to monitor endogenous bioluminescence in plant leaves. BMC Plant Biology. 2004; 4: 19.

56. Roach T, Colville L, Beckett RP, Minibayeva FV, Havaux M, Kranner I. A proposed interplay between peroxidase, amine oxidase and lipoxygenase in the wounding-induced oxidative burst in Pisum sativum seedlings. Phytochemistry. 2015; 112: 130-138.

57. Minibayeva F, Kolesnikov O, Chasov A, Beckett RP, Luthje S, Vylegzhanina N, Buck F and Bottger M. Wound-induced apoplastic peroxidases activities: their roles in the production and detoxification of reactive oxygen species. Plant Cell Environment. 2009; 32: 497-508.

58. Roach T, Beckett RP, Minibayeva FV, Colville L, Whitaker C, Chen H, Bailly C, Kranner I. Extracellular superoxide production, viability and redox poise in response to desiccation in recalcitrant Castanea sativa seeds. Plant Cell Environment. 2009; 33: 5975.

59. Whitaker C, Beckett RP, Minibayeva FV, Kranner I. Production of reactive oxygen species in excised, desiccated and cryopreserved explants of Trichiliadregeana. South African Journal of Botany. 2010; 76: 112-118.

60. Li JLY, Sulaiman M, Beckett RP, Minibayeva FV. Cell wall peroxidases in the liverwort Dumortiera hirsuta are responsible for extracellular superoxide production, and can display tyrosinase activity. Physiologia Plantarum. 2010; 138: 474-484.

61. Liers C, Ullrich C, Hofrichter M, Minibayeva FV, Beckett RP. Oxidoreductases from lichenized ascomycetes: purification and characterization of a heme-peroxidase from 

Biology 2011; 48: 1139-1145.

62. Rea G, Metoui O, Infantino A, Federico R, Angelini R. Copper amine oxidase expression in defense responses to wounding and Ascochyta rabiei invasion. Plant Physiology. 2002; 128: $865-875$. oxidase is a hydrogen peroxide source in the oxidative response to the protein phosphatase inhibitor cantharidin in Zea mays L. Journal of Experimental Botany. 2006;

64. Yoda H, Hiroi Y, Sano H. Polyamine oxidase is one of the key elements for oxidative burst to induce programmed cell death in tobacco cultured cells. Plant Physiology. 2006; 142: 193-206.

65. Angelini R, Tisi A, Rea G, Chen MM, Botta M, Federico R, Cona A. Involvement of polyamine oxidase in wound healing. Plant Physiology. 2008; 146: 162-177.

66. Roy P, Roy SK, Mitra A, Kulkarni AP. Superoxide generation by lipoxygenase in the presence of NADH and NADPH. Biochimica et Biophysica Acta. 1994; 1214: 171-179.

67. Upchurch RG. Fatty acid unsaturation, mobilization, and regulation in the response of plants to stress. Biotechnology Letters. 2008; 30: 967-977.

68. Higdon A, Diers AR, Oh, J, Landar Y, Darley-Usmar VM. Cell signalling by reactive lipid species: new concepts and molecular mechanisms. Biochemical Journal. 2012; 442: $453-464$. 
562

563

564

565

566

567

568

569

570

571

572

573

574

575

576

577

578

579

580
69. Groenendaal Jonas F, Freitag D, Pielartzik H, and Reynolds JR. Poly(3,4 ethylenedioxythiophene) and Its Derivatives: Past, Present, and Future. Advanced Materials. 2000; 12: 481.

70. Yuasa, M and Oyaizu, K. Electrochemical Detection and Sensing of Reactive Oxygen Species. Current Organic Chemistry. 2005; 9: 1685.

71. Yuasa M, Oyaizu K, Yamaguchi A, Ishikawa M, Eguchi K, Kobayashi T, Toyoda Y, and Tsutsui S. Electrochemical sensor for superoxide anion radical using polymeric iron porphyrin complexes containing axial 1-methylimidazole ligand as cytochrome c mimics. Polymers for Advanced Technologies. 2005; 16: 287-292.

72. Di J, Bi S, Zhang M. Third-generation superoxide anion sensor based on superoxide dismutase directly immobilized by sol-gel thin film on gold electrode. Biosensors and Bioelectronics. 2004; 19: 1479-1486.

73. Brett CMA and Brett AMCFO. Surface modified electrode-reasons and advantages" in Surface Engineering: Surface modification of materials, R. Kossowsky and S.C. Singhal, Ed., pp. 656-664, Westinghouse R \&D center, Pittsburg, USA. 1984.

74. Prasad A, Kikuchi H, Inoue KY, Suzuki M, Sugiura Y, Sugai T, Tomonori A, Tada M, Kobayashi M, Matsue T and Kasai S. Simultaneous Real-Time Monitoring of Oxygen Consumption and Hydrogen Peroxide Production in Cells Using Our Newly Developed Chip-Type Biosensor Device. Frontiers in Physiology. 2016; 7: 109. 


\section{Table $\mathbf{1}$ (on next page)}

\section{Calculation}

Superoxide anion radical $\left(\mathrm{O}_{2}{ }^{\cdot-}\right)$ concentration calculated using standard calibration curve $\left(R^{2}=0.9918\right)$ (Fig. 2). The total change in oxidation current was found to be $1.5 \mathrm{nA}(\Delta \mathrm{i})$ for minimal dose of injury (Fig. $4 \mathrm{~A}$ ) and $7.5 \mathrm{nA}(\Delta \mathrm{i})$ for injury at multiple sites (Fig. 4B). The total $\mathrm{O}_{2}{ }^{\cdot-}$ concentration was found to be equivalent to $40 \mathrm{nM}$ (Fig. 4A) and $200 \mathrm{nM}$ (Fig. 4B) at 60 sec and $300 \mathrm{sec}$, respectively. 
1

2

3

4

5

6

\begin{tabular}{|c|c|c|}
\hline & $\mathbf{A}$ & $\mathbf{B}$ \\
\hline$\Delta \mathbf{i}(\mathbf{n A})$ & 1.5 & 7.5 \\
\hline$\Delta \mathbf{t}(\mathbf{s e c})$ & 60 & 300 \\
\hline $\mathbf{O}_{\mathbf{2}}^{\cdot-(\mathbf{n M})}$ & $\mathbf{4 0}$ & $\mathbf{2 0 0}$ \\
\hline
\end{tabular}

7

8 


\section{Figure 1 (on next page)}

Reaction mechanism and experimental setup.

(A) Schematic illustration of the reaction mechanism for the amperometric detection of $\mathrm{O}_{2}{ }^{--}$-using the polymeric iron-porphyrin-based modified carbon electrode depicting the reduction-oxidation cycle leading to generation of the oxidation current. (B) Schematic illustration of the experimental setup for the electrochemical measurements. The stimulation was performed using a glass capillary, and the polymeric iron-porphyrin-based modified carbon electron was positioned at a distance of $1 \mathrm{~mm}$ using a motor-driven XYZmicroscopic stage (I). Thein vivogeneration of $\mathrm{O}_{2}{ }^{-}$-was measured using a polymeric iron-porphyrin-based modified carbon electron (working electrode, WE), platinum wire (counter electrode, CE) and $\mathrm{Ag} / \mathrm{AgCl}$ (reference electrode, RE) (II). 
A

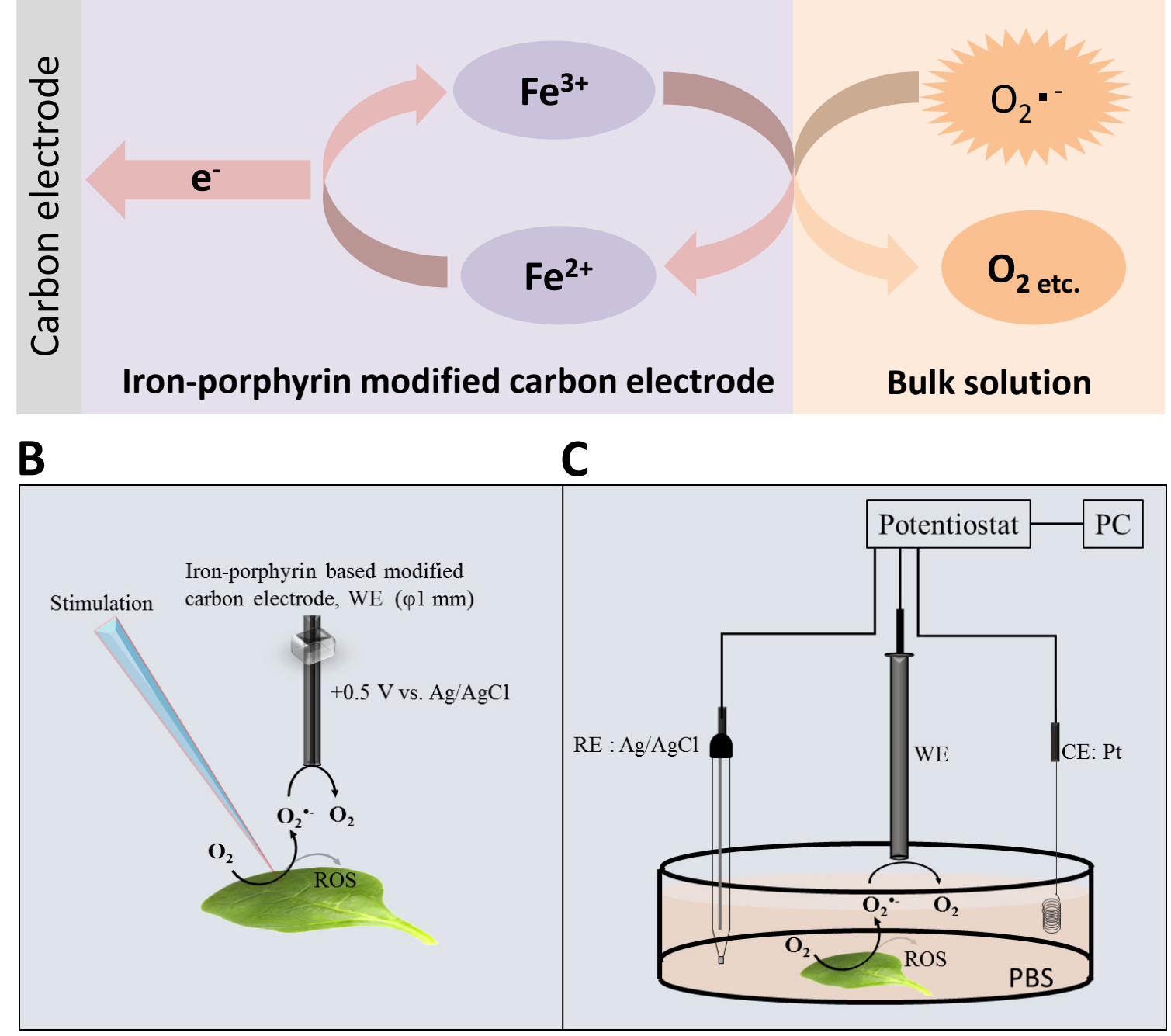




\section{Figure 2 (on next page)}

\section{Calibration curve}

Changes in oxidation current measured using iron-porphyrin-based modified carbon electrode by exogenous addition of a standard known concentration of $\mathrm{O}_{2}{ }^{\cdot-}$ generated in situ using $\mathrm{X} / \mathrm{XO}$ system in the concentration range of 0.4 to $1.3 \mu \mathrm{M}$. 


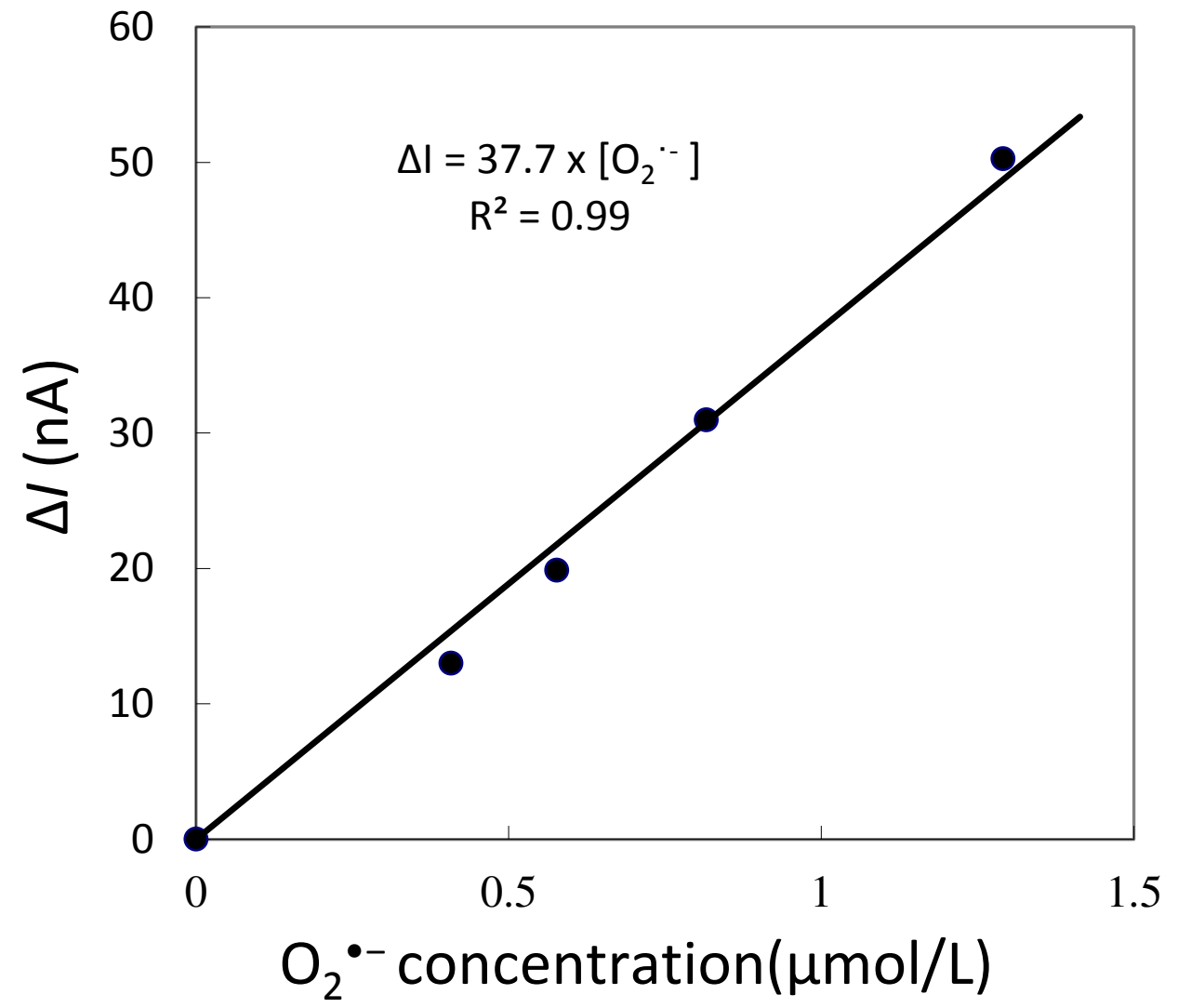




\section{Figure 3 (on next page)}

Real-time monitoring of the oxidation current of $\mathrm{O}_{2}{ }^{--}$from spinach leaves.

The kinetics of the production of $\mathrm{O}_{2}{ }^{\cdot-}$ was measured using a polymeric iron-porphyrin-based modified carbon electrode on non-wounded spinach leaves. 


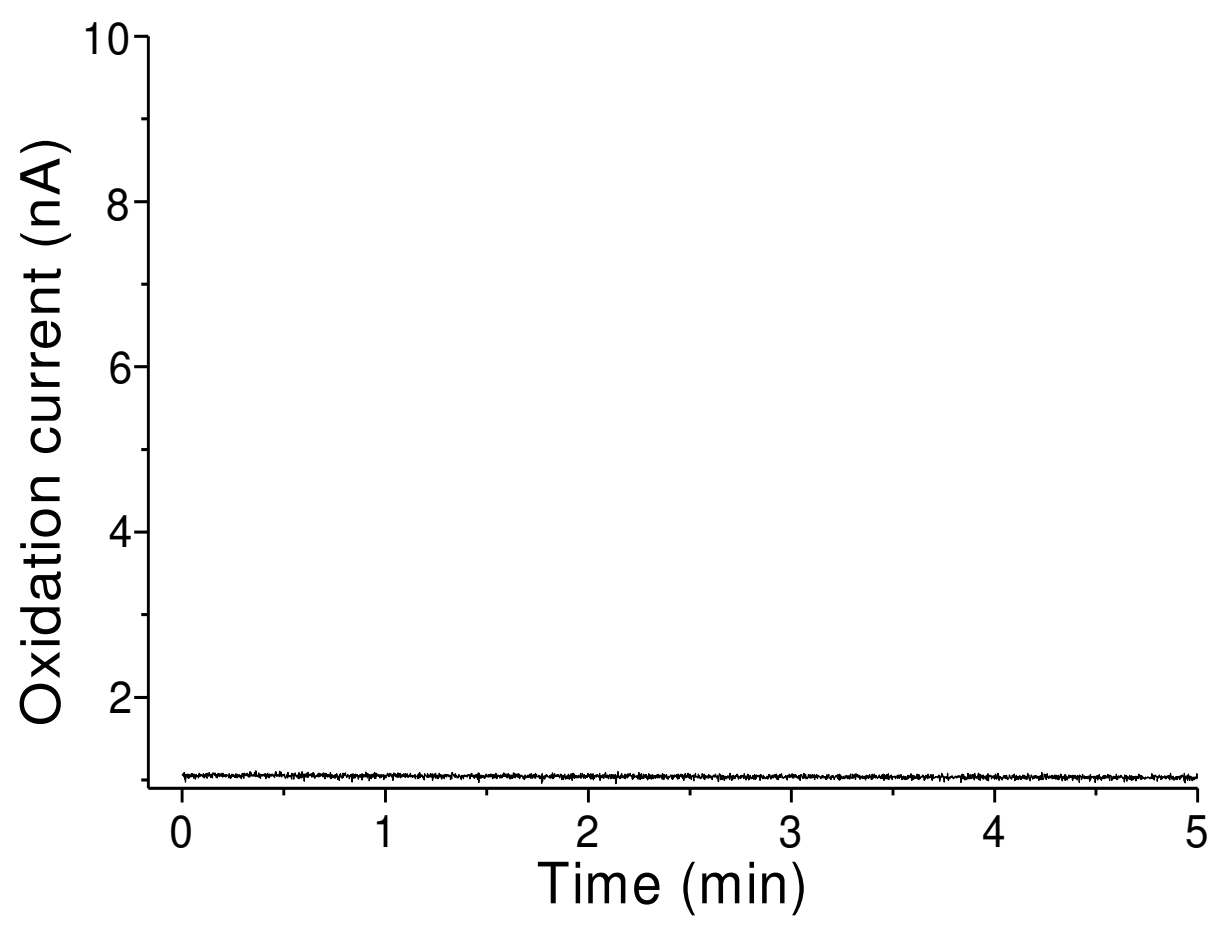




\section{Figure 4 (on next page)}

Real-time monitoring of oxidation current for $\mathrm{O}_{2} \cdot{ }^{-}$during wounding

The kinetics of the production of $\mathrm{O}_{2}{ }^{\cdot-}$ were measured using a polymeric iron porphyrin based modified carbon electrode during wounding in spinach leaves. The wounding in spinach leaves was done 1 time (A) and multiple times (B) close to the site of electrode during the measurement and oxidation current for $\mathrm{O}_{2} \cdot-$ was measured. 

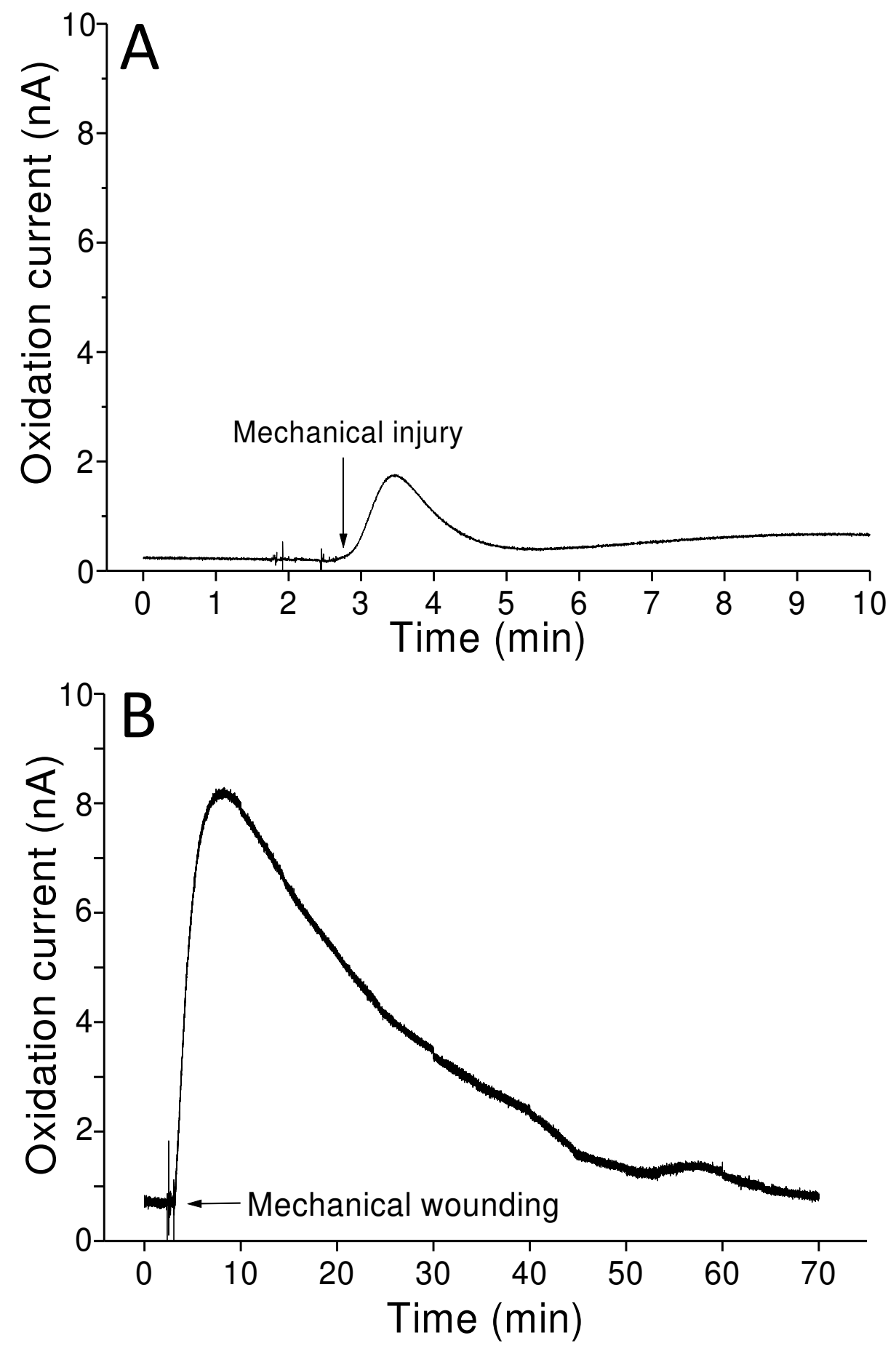
Figure $\mathbf{5}$ (on next page)

Real-time monitoring of the oxidation current of $\mathrm{O}_{2}{ }^{--}$-during wounding

The kinetics of the production of $\mathrm{O}_{2}{ }^{-}$-were measured using a polymeric iron-porphyrin-based modified carbon electrode during wounding in spinach leaves. The wounding of spinach leaves was performed during the measurement, and the oxidation current for $\mathrm{O}_{2}{ }^{--}$was measured for approximately $30 \mathrm{~min}$. The effect of SOD on the oxidation current was measured in the presence of SOD (400 $\left.\mathrm{U} \mathrm{ml}^{-1}\right)$ added exogenously during the measurement. 


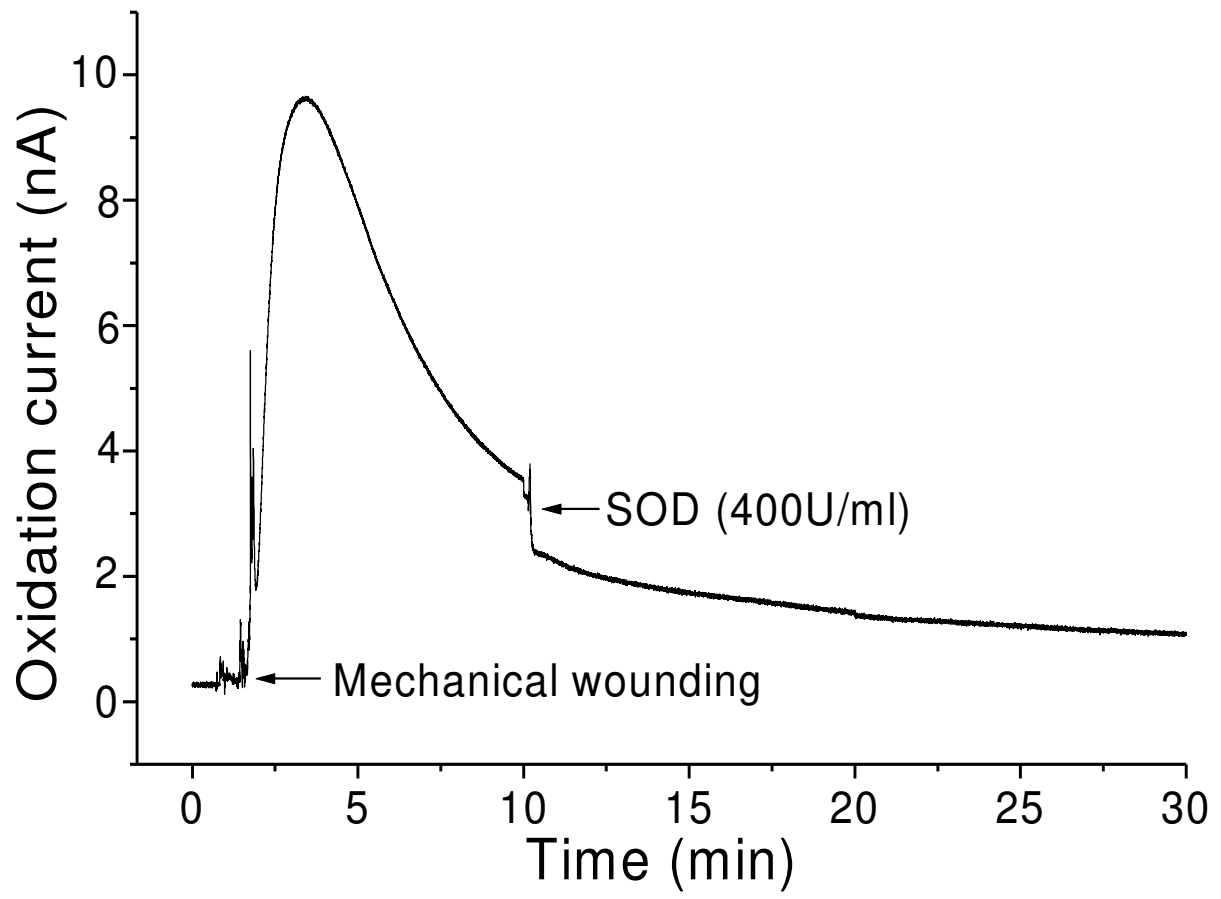




\section{Figure 6 (on next page)}

Real-time monitoring of oxidation current for $\mathrm{O}_{2}{ }^{--}$-during wounding.

The kinetics of the production of $\mathrm{O}_{2} \cdot{ }^{--}$was measured using a polymeric iron porphyrin based modified carbon electrode during wounding in spinach leaves. The wounding in spinach leaves was done during the measurement and oxidation current for $\mathrm{O}_{2}{ }^{-}$-was measured for a duration of about $30 \mathrm{~min}$. Effect of SOD was measured in the presence of SOD (400 $\left.\mathrm{ml}^{-1}\right)$ added exogenously during the measurement at the point of maximum oxidation current. 


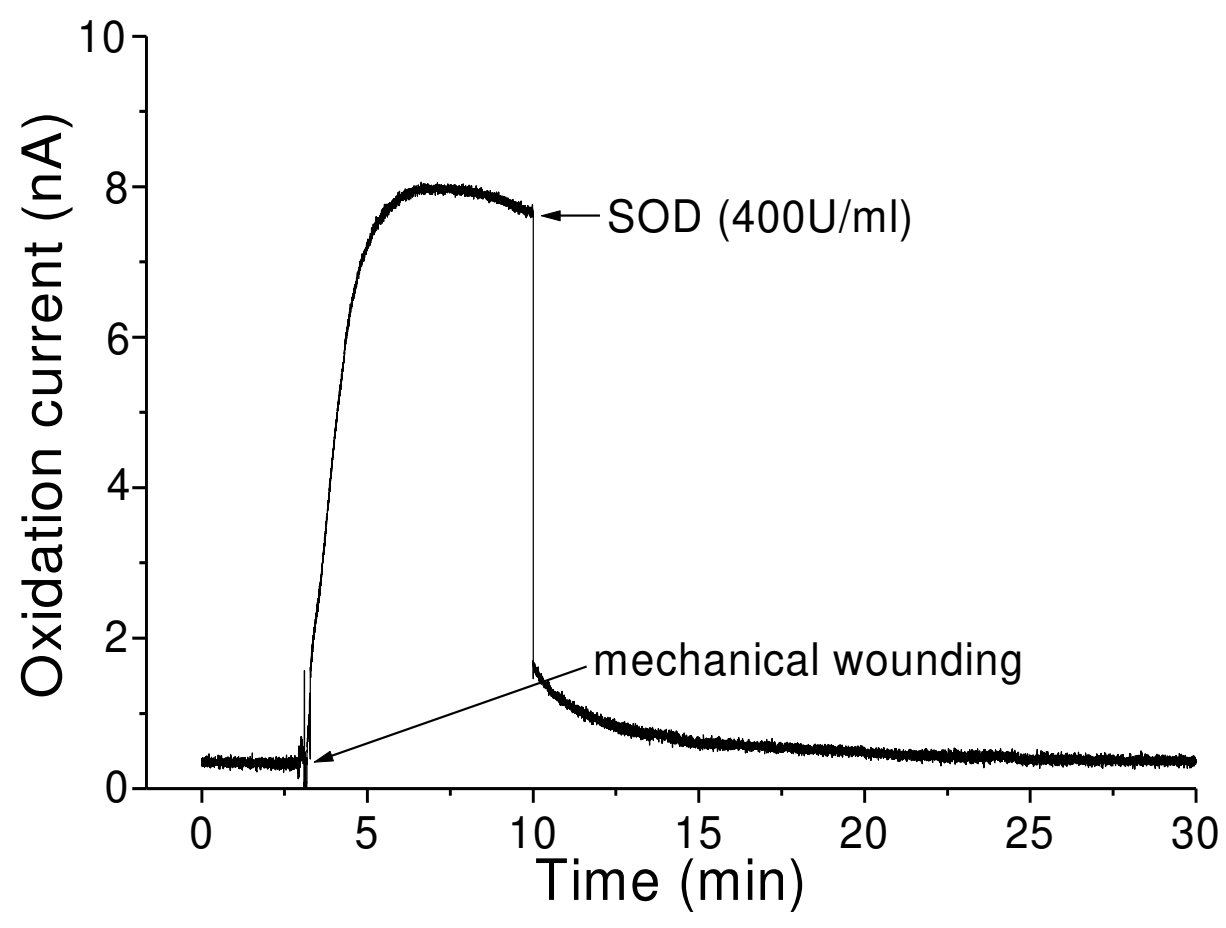

